\title{
Empowerment through participation in local governance: the case of Union Parishad in Bangladesh
}

\section{0}

Received 28 October 2018 Revised 6 February 2019 26 February 2019 Accepted 8 March 2019
HKPAA

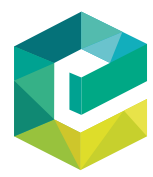

Public Administration and Policy Vol. 22 No. 1, 2019 pp. $40-54$

Emerald Publishing Limited 1727-2645 DOI 10.1108/PAP-10-2018-0002

\author{
Nasir Uddin \\ Department of Public Administration, \\ University of Chittagong, Chittagong, Bangladesh
}

\begin{abstract}
Purpose - The traditional concept of people's participation through their representatives is changing to the mechanism of direct participation of community people in the local governing process. In coupling with these, the Constitution of Bangladesh and the local government acts guarantee to foster the direct participation of people in the formation of local bodies and development programs. The purpose of this paper is to explore the avenues of people's participation in local government, particularly the Union Parishad (UP) in Bangladesh, and to evaluate the empowerment of marginalized community through those avenues.

Design/methodology/approach - Using a broad descriptive and analytical approach, this paper evaluates the relationship between participation and empowerment of local community based on the review of secondary sources of information.

Findings - The local government institutions, particularly UP, has existed many mechanisms through which people participate in decision-making process. It is also believed that participation of community people in local government institutions is not only an opportunity for them but also an apparatus of empowerment. Hence, the process of empowerment is entrenched in the notion of participation. It is evident that the people at grass root level have been participating in UP in diverse arrangements, but the effectiveness of these participations in terms of empowerment is still meager and even lack.

Originality/value - Though a long time has passed after introducing these participatory mechanisms, very few studies have undertaken to assess the people's participation in local government. Additionally, no single initiative was undertaken to assess how empowerment of marginalized people happened through these initiatives as empowering community people is the key objective of it.
\end{abstract}

Keywords Bangladesh, Participation, Local government, Empowerment, Union Parishad

Paper type Research paper

\section{Introduction}

Popular participation in governance that affects their lives is an indispensable part in contemporary democratic society. Globally, decentralized approaches have been adopted as a sustainable solution for local community that improve service delivery, accommodate marginalized community in governing process and allow citizens to participate in formulating and implementing the decisions, development plans and policies. The perceived benefits of decentralization are greater access to decision makers, higher level of participation by various social groups in decision making and accountability of decision makers (Andersson et al., 2004). Local people are empowered directly through decentralization as of involving local people, including civil society in planning and implementing public programs and policies (Roche, 2010; Uddin, 2017). Participation by the local population is a requisite ingredient in development activities because it integrates people's experience, knowledge and commitments in the development process, while upholding democratic values (Panday and Rabbani, 2011). Popular participation in decentralized governance is seen as a dynamic process by which

(C) Nasir Uddin. Published in Public Administration and Policy: An Asia-Pacific Journal. Published by Emerald Publishing Limited. This article is published under the Creative Commons Attribution (CC BY 4.0) licence. Anyone may reproduce, distribute, translate and create derivative works of this article (for both commercial and non-commercial purposes), subject to full attribution to the original publication and authors. The full terms of this licence may be seen at http://creativecommons.org/licences/by/4.0/legalcode 
people influence the direction and implementation of a development program with a view to upholding their well-being in terms of income, self-growth, independence or other values they cherish (Denhardt et al., 2009; Martinelli, 2005). Particularly, the inclusion of poor people and other traditionally excluded groups, including females in priority setting and decision making, is also imperative to ensure that limited public resources build on local knowledge and priorities (The World Bank, 1994). The people's participation in local governing process has immense benefits for the local institutions as well as the community. It appears both to reveal preferences and to keep costs down (Bird, 1995). Additionally, participation not only empowers people but also empowers local government officials to develop ways by which effective participation may occur (Koenig, 2005).

Recently, the local government in Bangladesh has started to exercise democratic and participatory governing processes at grassroots level. There are some formal mechanisms of ensuring community participation in planning, implementing and monitoring. It is expected that civic participation in local decision making takes place as the elected representative are supposed to be accountable to the people for the money paid by the local citizens as taxes. Citizen might complain about their local government and the services and try and change them but that usually revolves around voting out incumbents, not moving. Moreover, it would require substantial numbers of people or businesses to relocate to influence government to alter its policies and services (Hamilton, 1999, 2012). Similarly, the Union Parishad (UP) as a unit of local government institutions ensures effective participation of all stakeholders and promotes community empowerment and produce improved service delivery and sustainable decisions. The provision for people's participation has opened up a new avenue for the general people other than people's representatives to work for the local government bodies. The rationality for incorporating popular participation mechanisms in UPs is that local people are expected to engage directly with UP to identify and solve their problems relating to their livelihoods, and to bargain with the UP functionaries. At the same time, the elected representatives are supposed to be able to identify their areas of priority needs, and make sustainable decisions with the help of local expertise. Simultaneously, transparency and voters' trust on elected functionaries are likely to enhance through dissemination of information on income, expenditure, project beneficiary list, project list and so on.

Various recent studies have shown that popular participation in the affairs of the local government bodies are significantly increasing in an effective manner and people are trying to make their presence felt and their voices heard. It is indeed argued that elected officials are interested and focus on efficiency in service delivery and less concerned with fostering means of public participation (Zeemering, 2008) because people's participation at the local level has remained controversial as of the existence of the patron-client relationship in the rural society. Moreover, the structure of the UP is such that the chairman has a disproportionate role in decision making, and the general ward members or women of the reserved seats play a secondary role. Procedurally, ward assemblies or committees can make recommendations to the council and the council makes the decisions. However, in the case of decision making in the council, the chairman is the final authority (Sultan, 2018). Indeed, many of participants have complained that their views are disregarded by the chairman (Panday, 2008). Local government being a sub-system of national government, female's involvement and representations are also essential for a political point of view. They play a special role in representing women's interests and responding to their needs (Panday, 2008, 2013; Nazneen et al., 2014). They are participating in the UP meetings in various public forums and also raising different issues concerning budgeting and planning, project implementation and scheme selection (Sultan, 2018). But other studies have also shown that female-elected representatives face various structural and attitudinal barriers (Panday, 2008; Nazneen and Tasneem, 2010). Therefore, it is imperative to assess the progress of regime opening in terms of people's participation in UP and reveal the factors 
hindering the reform. This paper is descriptive and qualitative in nature based on secondary sources of information, attempting to examine the empowerment of grassroots people through the mechanisms of popular participation adopted in the UP in Bangladesh. In this regard, this paper initially conceptualizes broad two themes, namely, empowerment and participation, and discusses the local government structure in Bangladesh, together with historical overview of UP. The paper also critically evaluates to what extent those mechanisms in UP activities empowered locals to hold service providers accountable and transparent to them, along with special emphasis on female participation.

\section{Conceptualizing empowerment and participation}

Participation and empowerment are crucial elements for socio-political development of any nation. Empowerment is regarded as a process of external and internal change. The external change is known as political empowerment which finds expression in the ability to act and to implement the practical knowledge, the information, the skills, the capabilities and the other new resources acquired in the course of the process whereas the internal change is the person's sense or belief in her ability to make decisions and to solve her own problems (Parsons, 1988). Empowerment happens on an individual, organizational and community level that may be termed as individual, organizational and community empowerment. Individual empowerment is an expression on the individual level of a multi-leveled process which may be applied to organizations, communities, and social policy (Zimmerman and Rappaport, 1988). Community empowerment is a social action process by which individuals, communities and organizations gain mastery over their lives in the context of changing their social and political environment to improve equity and quality of life (Wallerstein, 1992). Individual change is a prerequisite for community and social change and empowerment (Wilson, 1996). There are four mechanisms that are important to empower poor people, increasing their freedom of choice and action in different contexts. These mechanisms, namely, access to information, inclusion and participation, accountability and local organizational capacity, are closely intertwined and act in synergy (Narayan, 2002).

People's participation is one of the core issues of democratic and decentralized governance. Participation is a means of exercising influence and bargaining power, when it creates an environment through distribution of power and ownership among the officials and the ordinary people (Isham et al., 1995). The World Bank (1994) defines participation as a process through which stakeholders influence and share control over development initiatives, and the decisions and resources which affect them. Moreover, Bhatanngar and Williams (1992) also define participation as a function of information through which people can come to share a development vision, make choices and manage activities. Finally, people's participation is the process by which members of a society share power with public officials in making substantive decisions and in taking actions related to the community (Roberts, 2004). In addition, participation within organizations is considered to be an important component of the overall participatory process (Vigoda and Golembiewski, 2001). It is also argued that access to information, accountability and local organizational capacity is also imperative through the inclusion and participation of community people at local government level.

In Bangladesh, UPs have several direct (when citizens are personally involved and actively engaged) and indirect (when citizens elect others to represent them) avenues of popular participation which make the local government more accountable and transparent to the community. The direct avenues are, for example, setting up participatory budgeting (open budget session), community based meeting (Ward Shava), standing committees and others special committees, and access to information (Local Government Division, 2009; CPD, 2013). Additionally, the election is the only mechanism of indirect participation of local people in governing system. Besides, a UP has been entrusted with the responsibilities to 
run the village court system. The present form of a local court gives the more opportunity of people's participation in the adjudication process. For example, the victims and offenders have an active role and right to participate in the choice of the adjudicators, since the parties themselves nominate four out of the five members of the forum (Khan and Rahman, 2009). Particularly, the key objective of the courts is to provide and ensure justice for all at root level as well as protect rural poor people through empowering community people, particularly women, poor and disadvantaged groups to seek remedies for injustices (Sarker, 2013). All these provisions are made for involving people in the decision-making process, and in ensuring accountability and transparency of the total process.

\section{Local government structure in Bangladesh}

The existing structure of local government in Bangladesh is nothing but a result of changes during successive regimes. The constitution of Bangladesh preserves the provision of elected representative bodies at all levels of administrative tiers with powers to prepare budgets, maintain funds, impose taxes, and implement plans for public services and economic development (Government of Bangladesh, 2008). The administration of Bangladesh is divided into nine administrative units called divisions. Each division is spilt into several districts which are further subdivided into Upazila (sub-districts). Each sub-district is further divided into several unions, except for those in metropolitan areas. At present, there are two distinct types of local government institutions in Bangladesh: one for rural areas and the other one for urban areas. The local government in rural areas represents a hierarchical system consisting of three tiers: UP at the village level, Upazila Parishad at the sub-district level and Zila Parishad at the district level, while urban local government are the city corporation for large cities and the Paurashava (municipality) for small towns (CPD, 2013). There exist separate laws for each tier of local government. In the three hill districts of Chittagong hill tracts, the system of local government appears iron fisted and more complicated one because of the existence of dual governing system. Here traditional local government is functioning under the circle chief along with the general system (Barkat et al., 2015). Figure 1 shows the existing structure of local government in Bangladesh.

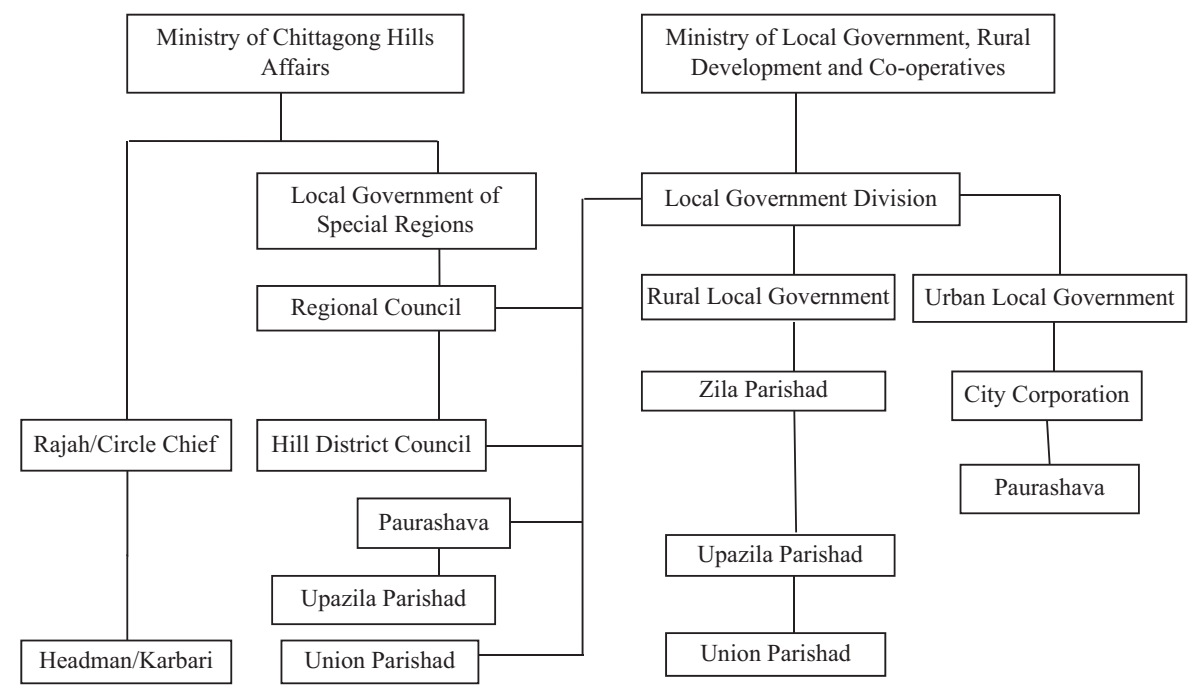

Source: Barkat et al. (2015) 
PAP

22,1

44

The composition and functions of city corporation and municipality are more or less similar. A city corporation has comparatively more wards and wider jurisdictions than municipality. A city corporation or a municipality consists of a mayor and councilors. Like other local bodies, one-third of the total seats are made reserved for women councilors. The number of councilors is fixed by the government depending on the size of the city. The mayor and councilors of municipality or city corporation are directly elected on the basis of adult franchise for the tenure of five years.

The first tier of rural local government in Bangladesh is Zila Parishad which, in fact, is the apex local government institution. The elected chairman (but now selected by the government) is the executive head of the council. He is assisted by 15 members of whom five seats are reserved for female members. The Upazila Parishad is considered as most significant tier in terms of strengthening local government as far as decentralization and devolution of power are concerned (Barkat et al., 2015). Currently, each Upazila council has an elected chairman and two vice-chairmen of whom one is reserved for female. All representatives are elected through direct popular election. The elected chairmen of the UP and mayor of municipality (if any) within the sub-district level and the one-third of female member who are elected among elected female members of UP and municipality become the members of the Upzila Parishad. The government officials at sub-district level are the ex-officio members of the council without having a voting right (Figure 2).

The UP is the bottom tier of the local government institutions in Bangladesh which provides services to citizens at their doorstep. According to the provision of the Act, a union is divided into nine wards which are considered as its jurisdiction. A UP is made up of 13 members having 1 chairman and 9 elected members and 3 female members from reserved seats (Local Government Division, 2009). To assist necessary supports to UP, there is a provision for one secretary and one computer operator cum accountant and ten village police, including Dafadars. The Local Government (UP) Act of 2009 is the milestone in the history of Bangladesh aiming at to ensure people's empowerment and good governance in the governmental organizations. This Act confers UP to perform more around 40 functions, which included civic and public welfare, infrastructures, revenue, development and judicial under limited capacity. The UP is the only local government body that has been operating for decades with regular elections (Sarker, 2003).

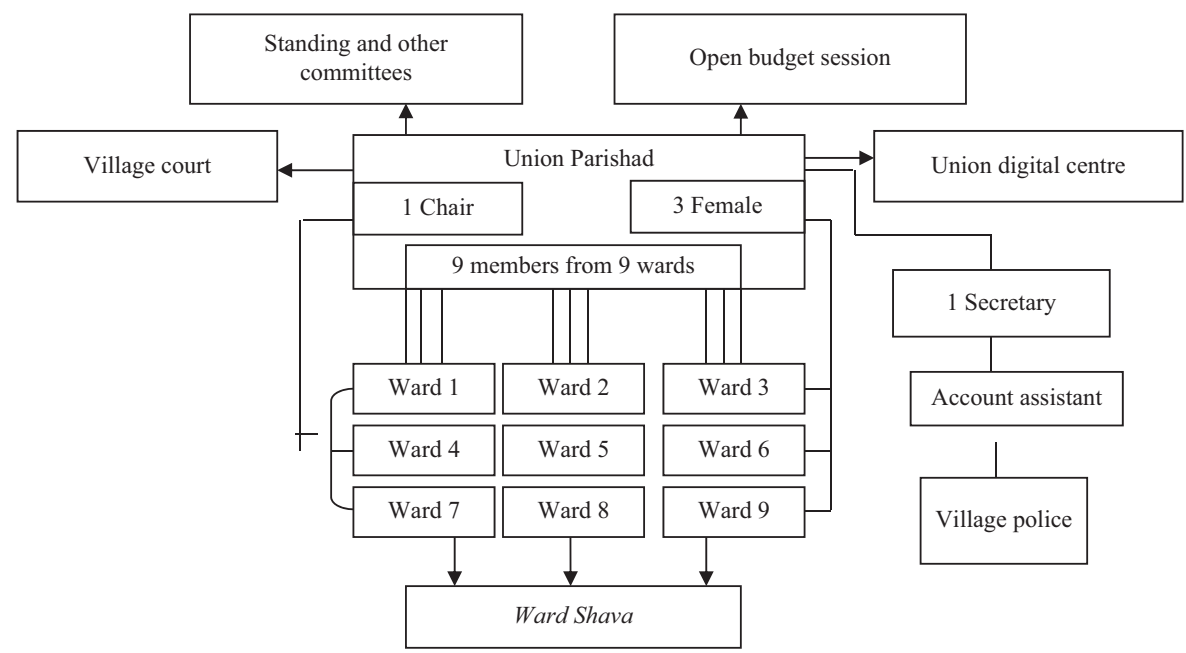

Figure 2.

Organizational and functional structure of Union Parishad
Source: Modified from local government (Union Parishad) Act of 2009 
The local government in Bangladesh has been found in the subcontinent since ancient time, but appeared as a representative character during the British rule in India (Barkat et al., 2015). The people's participation in local development works remains deeply rooted in the dynamics of the evolution of local government bodies. Local government institutions and the mechanism of people's participation with those agencies have changed in tune with the changes of the socio-political situation. In ancient time there were autonomous and selfsufficient institutions popularly known as village republics where the common people had access to involve in the decision making process (Litvack et al., 1998; Siddiqui, 2005). The concept of village republic was later transformed to village panchayet where local people could also discuss their affairs with the central employees.

During the British rule in India, numerous attempts were experienced to encourage community engagement in the local government institutions. In these respects, the first attempt was the village panchayet consisting of five local people to appoint village police under the Village Panchayet Act of 1870 (Siddiqui, 2005). After then, the union committee under the Bengal Local Self-Government Act of 1885 and later the union board under the Bengal Village Self-Government Act of 1919 were substantiated to ensure people's participation at grassroots level. Though these Acts were called selfgovernment, these bodies were not self-governed rather controlled by the central government directly or by proxy (Sarker, 2006). The real purpose behind the introduction of local bodies was seeking support from the natives at the local level while denying their participation at the central level (Morshed, 1989). In addition, there were no formal mechanisms or institutions for civic participation or citizen's voice in local government (Rahman et al., 2004). During the Pakistan period, four tiers of local government system were introduced under the basic democracy order of 1959. The union council, consisting of elected representatives from each unit, was the basic foundation for people's participation in the governing process. But rather than serving the people, these people's representatives served the government officials to continue their power exercise (Siddiqui, 2005; Sarker, 2006).

After the emergence of Bangladesh as an independent state in 1971, the local government bodies in Bangladesh have experienced significant changes in their structure and functions in concurrence with constitutional sprit as well as several successive governments in Bangladesh undertook a number of reform efforts aiming to increase people's participation in the governing of local government process (Panday and Rabbani, 2011). Particularly with the change of government in 1976, 1982, 1991, 2001 and 2006, there were changes in the structures and nature of people's participation in local government (Waheduzzaman, 2010). But the Government of Bangladesh is endlessly striving to make local government institutions more operative and participatory. Among other reforms, the Local Government (UP) Act of 2009 (and subsequently amended later) was the milestone initiative of the government in the history of UP. The local people in rural Bangladesh have been participating in development programs in different forms, but the effectiveness of these participations is still low (Aminuzzaman and Sharmin, 2006).

\section{Empowerment through participation: an assessment}

The Local Government (UP) Act of 2009 ensures the provisions for inclusion of local residents and elected representatives in different committees, meetings, Ward Shava and other activities of the council (Table I). People's participation in decisions and development works that has an effect in their lives is, therefore, perceived as an instrument of empowerment because local people get empowered to raise their voices in government decisions (Denhardt et al., 2009; Holzer and Kloby, 2005). 
Open budget session

Ward Shava

Village court

Standing committees and others

Local election UP election held after every five year interval

Access to information

Table I. Avenues of people's participation in UP
A court consists of a chairman and four members: of four members, two members from community people out of UP; and meeting: at least once in a week 13 standing committees on specific functional matters lead by a UP member with five to seven members and other co-opt person; and organize meeting at least bi-monthly

One open pre-budget and one final budget meeting: 60 days before the financial year

A Ward Shava consists of each ward with all the member will act as chairman and adviser, respectively; each ward to organize at least two meetings annually; and the quorum: five percent of the total voters of that ward

Major functions are to discuss and debate budgetary priorities; and prepare a budget for the next year and approve previous budget

Among 7 functions and 4 responsibilities: reviewing all the development activities and providing necessary support;

facilitating development planning; preparing and transferring final lists of SSNP beneficiaries and overseeing the progress of schemes; and uniting people of the ward, building organizations and social awareness programs and arranging sports and cultural programs

A court can deal with cases of criminal and civil natures, where the amount sought for compensation falls below or equal BDT 75,000 (US\$900)

Monitoring the activities of service providers and giving feedback to the general people; give planning support to the service provider and monitor the implementing process; and provide regular reports to the UP

Direct avenues to make the representative accountable

Every citizen has the right to obtain information Provide the information upon the citizen's from the UP in any time Charter

\section{Open budget session}

Participatory budgeting is the process of inviting citizens to a public meeting to discuss budgetary priorities. Participatory budgeting describes the process in which citizens engage in debate and consultation to contribute to defining the balance of expenditures, investments, priorities and uses of public resources. The national and local government bodies arrange participatory budgeting to use information by the public in order to affect revenue and expenditure decision making (Vergara, 2002). Earlier, the budget making process in UP was highly centralized. There was no scope for people's participation. But, the Local Government (UP) Act of 2009 established a formal mechanism of people's participation in policy making process and budgeting at local level. As per UP Act 2009, the UP is required to organize two open budget sessions every year, once in February and once in April. The UP informs and invites the community people irrespective of gender, sex, caste, class status to participate in the session. In the budget session, the UP generally shares the proposed budget, including income and expenditure and revised budget, and invites feedback from participants. It is to be noted that the proposed budget is prepared based on the recommendations of Ward Shava. Then, the participants discuss on budget and provide their comments and recommendations to incorporate in the final budget. After incorporating feedback from the open budget session, UPs approve the final budget in their full meeting. The final budget is then made public by hanging it in the notice board.

The aim of the open budget session is to discuss and debate the UP budget to ensure the representatives' accountability through people's voices. The open budget session is one of the most imperative tasks of UP which entails projection of income and expenditure of the 
UP before the people. People can raise questions, queries and make comments on any of the issues of the proposed budget and plan (Ahmed et al., 2016). Open session creates an opportunity for local people to address their demands as well as to participate in the decision-making process and development activities, and make the council accountable for their work (Chowdhury, 2018). The local people also feel honored to have access in local bodies. Conversely, it also creates scope for the UPs to mobilize more local resources by creating awareness and motivating local people to pay their taxes. It also gives them an opportunity to have support from community in implementing development projects as they can show credible transparency and accountability in their activities through open budget sessions (Rahman et al., 2004).

\section{Ward Shava}

Ward Shava is another formal mechanism for participation in UP that enshrined detailed in the Act (Articles 4-6). Ward Shava is a citizen gathering, composed of all individuals enlisted in the voter list of a ward, and conducts meetings chaired by the respective ward member under the advisorship of female member. According to the Act, there is a provision for arranging two open meetings a year at every ward level by ensuring a sufficient number (at least 5 percent of total voters) of participation from local people. To ensure the attendance of Ward Shava members, the UP circulates a public notice at least seven days before the meeting takes place. During these meetings, information on current development activities, financial affairs and schemes are provided to allow citizens to evaluate the activities of UP. Furthermore, the Ward Shava can propose projects, prioritizes schemes and development programs to be implemented, identify and prioritize the beneficiaries of social safety net programs, review UP reports and identify shortcomings (Ahmed et al., 2016). After incorporating feedback from participants, the Ward Shava put forward a report to UP.

Ward Shava is an effective mechanism for encouraging people to express their opinions and views about UP activities. It ensures people's participation in the development planning process and makes the local representatives accountable to them. Ward Shava meetings have been conceived as a forum for the unheard voices of the deprived people, especially village women, which is supposed to give them voice to raise their problems to UP system. In the meeting, they have the opportunity to exchange information and opinions on community affairs. Community budgets would be a typical example of public hearings. This mechanism is considered as an important tool to raise citizen's concerns in front of elected officials and bureaucrats, thus providing important feedback to the officials regarding citizens' experiences and views.

\section{Village court}

An UP is entrusted to resolve petty disputes both civil and criminal at local level through a village court under the provisions of the village courts Act of 2006. The village court is a quasi-judicial and semi-formal court. The village court is governed by the UP under the leadership of the chairman, along with the other four members, of whom at least two from UP members. There is also a provision of choosing two persons, one from each party, in forming a five-member judge panel from outside of the elected representatives to represent them. There is legal guidance as to decision making of both the village courts. So, legally, there is no scope for making an arbitrary decision, nor is there any scope for the village leaders to poke their nose in the decision making (Islam, 2015). The open forum hearing system is helping to enhance increased sense of ownership over the local peace building process and promotion of communal harmony. Given the fact of resolving matters related to the interest of women or minorities, the provision of incorporating a woman member has made mandatory in the law. There are claims that 
PAP

22,1

these Shalish systems are largely unfair, biased, anti-poor and ant-disadvantaged people. To fight this bias and prejudice in the Shalish system, and to provide the economically poor and vulnerable rural people with alternative justice systems, the village court was introduced quite a long time ago (Islam, 2015).

The underlying principle of the village court is that disputant parties can discuss their problems openly without hesitation, in an attempt to reach an amicable and sustainable decision, thereby helping to restore broken relationships. Availability of the judicial system at local level is the most important mechanism for empowerment. The village court is the best alternative for local people where they get justice in a very nominal expense and in a cordial and informal atmosphere due to over burden cases and inadequate access of poor people in the formal justice system. Moreover, many grievances which are never accessed to the formal justice system due to its formalities and for the cause of expense can be resolved through village courts and that would contribute substantially in establishing a rule of law (Local Government Division, 2010). It can also mention that the village court is closer and within easy reach of the villagers and, hence, geographically accessible to the poor and disadvantaged community of rural people as of the village court takes place at the UP complex, which is mostly located at the center of the union.

\section{Standing committees and other committees}

Another formal mechanism of participation is the committee system of UP. The Article 45 of the UP Act provides provision for establishing 13 standing committees on specific matters. As prescribed in law, a standing committee is headed by one UP member together with five to seven members. Moreover, there are provisions for incorporation of general people as coopted members in standing committees and other committees of UP. Officials of different government offices can become members of different committees. Each standing committee has to meet every two months, but emergency meetings can be arranged any time. Basically, the members of standing committees organize regular meetings among themselves to address the problems of the committee in their respective sectors, locality and find out the means and ways to resolve the problems in a structured manner. The head of the committee contacts possible members in order to invite them to participate; the invitation can be accepted or declined. The UPs are bound to deliberate and consider standing committee proposals and comments (Ahmed et al., 2016). In addition, the project implementation committee and other local management committees like market management committee and school management committee are important mechanism for community people to participate and oversee the development activities of UP. These committees are formed mostly by local people.

The main functions of the standing committees are to provide the planning supports along with monitoring the activities and implementing process of service providers. In addition, it also provides regular report to the UP and gives the feedback to the general people based on their needs and demand (Local Government Division, 2012). For community empowerment, there exists a provision for getting a co-opts member from the community. The decision is made on the basis of opinions of majority present in the meeting. Additionally, for women empowerment, the chairman of one-third of standing committees is made reserved for them in UP. Moreover, the PIC and other management committees are the formal avenues for empowerment of local people in local government. These are formed to monitor and evaluate the development activities of UP.

\section{Access to information}

People's right of access to information has a legal and constitutional basis in Bangladesh. The Article 39 of the Constitution of Bangladesh guarantees the freedom of thought, conscience, speech and expression as one of the fundamental rights. Additionally, the right 
to information Act and the Local Government (UP) Act of 2009 (Articles 78-81) recognize the people's right of access to information and ensures legal provisions for free flow of information. The access to information is not limited by any law that prevents information disclosure. According to the law, every citizen has the right to obtain information from the authority and the authority is obliged to provide the information upon the citizen's request. Similarly, the provision of the citizen's charter is incorporated in local government acts and makes it mandatory for establishing at every tier of local governments in Bangladesh. Under the Act (Article 49), the UPs are directed to adopt a citizen's charter with description of various types of services, terms and time limit for specific services; assurance of service; complaint address if failed rendering service and so on. The simple objective of the citizen's charter is to empower the citizen in relation to public goods and service delivery. Through the citizen's charter, citizens become well informed about their rights and entitlements. They can exercise considerable pressure on service providers to improve their performance. The availability and dissemination of information empower people. Since all powers of the Republic belong to the people, it is necessary to ensure right to information for their empowerment and accountability of the concerned establishment. To ensure free flow of information, the websites of all departments and information centers at district, Upazila and union levels have been set up (MRDI and Asia Foundation, 2013).

\section{Local election}

The election is considered to be one of the key avenues of indirect participation that enables citizens to exercise their choice in running the system. In a democratic system, an election is a process through which the people elect their representatives, local and national, to formulate policy and to supervise its actions (Uddin, 2016). In Bangladesh, the citizens of the republic have voting right to elect representatives as well as the right to participate either directly or indirectly in governing process. The UP election is the biggest election in Bangladesh in respect of voters and volume of units. In the election of 2015 , more than $60 \mathrm{~m}$ voters have franchised their voting rights. A large number of voters irrespective of male, female, aged, disabled and minorities were seen in the polling center and took part in the ballot (Uddin, 2016). The response of the voters was encouraging as around 76.66 percent of voters exercised their rights while the UP poll held in 2011 was recorded 70 percent of voter turnout. This average turnout is recorded as highest among all levels of local government elections. In UP elections of 1997, more than 60 percent voters had cast their votes (FEMA, 1998).

The local government's election not only is a mechanism to pick up representatives and hence make their institutions accountable to the people, but also a means of people's empowerment. The citizens of Bangladesh are more aware and are participating more fully in electoral process. The UP elections show different voter turnout in different years. In addition, the average turnover fluctuates in the elections to same institution in different phases in the same year. It is indeed mentioned that voter turnout in UP elections are recorded almost always over 50 percent and in many cases even over 85 percent. Free and fair elections provide the most obvious accountability, but this is a rather blunt tool, exercised only at widespread intervals and offering only the broadest citizen control over government. Elected members are, periodically, required to seek re-election, giving constituents the opportunity to pass judgment on the activities of individual members and councils as a whole. Voters can retain or reject their governors. An elected representative becomes more aware of their role and responsibilities because of future aspirations for contesting in elections.

\section{Female participation and empowerment}

After the independence of Bangladesh, the females of the country were given voting right along with the provision for greater participation in national life. The constitution of 
PAP

22,1

Bangladesh guarantees that equality of opportunity and participation of women in all spheres of national life. The constitution, furthermore, emphasize the state from making special provision in favor of women or children or for the advancement of any backward section of citizens. In 1997, the provision for direct elections for female was ensured to reserved seats in local level elections. The participation of female in the local government is also crucial to empowering and mobilizing female at the grassroots level so that they have a greater voice in the decision-making process. The government ensures the provision for one-third reserved seats for female in UP. Apart from the reserved seats, female can also contest for any of the general seats (Asian Development Bank, 2001). The introduction of the reserved seats for female has resulted in a substantial increase of female in local politics than ever before. This is a milestone in the history of political empowerment of female in Bangladesh. Furthermore, the government has already issued different executive orders to ensure female members' participation in various decision-making committees, including standing and others committee, and panel chairman of UP.

\section{Key challenges}

Open budget meeting is one of the platforms at the grassroots for ensuring participatory planning. The existing budget preparation process is efficient, transparent and a vehicle for effective participation of the poor, women, vulnerable, and voiceless. However, this platform is not practiced widely rather exercised in a limited scale. The Ups, in practice, invite a few local elites and political leaders in a small in-house discussion and prepares a proposed budget based on discussion meeting. Additionally, the UPs tend to claim that Ward Shava is being organized on a regular basis in most of the wards, but it is difficult to find evidences and findings to support it (Ahmed et al., 2016).

The Ward Shava system is not functioning the way it was perceived and envisioned in the Act. Although the Ward Shava is potentially an important space for citizens, its mode of operation is not spelt out in the law nor is any regulations provided for its working (Ahmed et al., 2016). Ward Shava has been very instrumental in sharing information about UP planning, budget and services for which the poorest are entitled. Several problems such as professional obligation, lack of personal interest, lack of awareness, political reasons and inappropriate meeting times discourage people's presence at the Ward Shava (Chowdhury, 2018).

Most of the UP representatives claimed that they have only formed standing committees. But most of the cases, the committees are not function effectively. Most of the members neither aware about the standing committees nor attend in the committee's meetings. There is also some overlapping of responsibilities in the committees (Ahmed et al., 2016). The main challenges of SCs are insufficient manpower, lack of terms of reference, limited scope of training and motivation of UP secretaries (Islam, 2016).

The actors associated with village court have limited knowledge about the rules and jurisdictions of village court. There is no training program for the UP functionaries for orientation on village courts. Moreover, village courts do not receive any budget allocation, limiting funds for logistics and documentation. It is also unclear how biased their decisions are, particularly given that the majority of the panel members are politicians. Although local elections may hold them accountable to the citizens in terms of providing fair judgments, they may be unwilling to rule against politically connected individuals.

UP is the institution for delivering information services to the local residents. However, very few of them get information on various services when they ask the chairman or secretary of UP. In most cases, reluctance was noticed on the part of the chairmen and secretaries to give access to information to UP members (Panday and Rabbani, 2011). Moreover, the websites of the UP provide broadly generalized information and do not update regularly. Additionally, people, particularly the vulnerable segment of society are 
unaware of this law. They cannot relate the right to information with solution of the problems related to their life and livelihoods.

Although female representatives in recent days have had an increased voice at the community level and have gained social legitimacy in representing certain types of women's issues, their participation in the UP activities is limited in some cases (Nazneen and Tasneem, 2010). Gender division of labor, restrictions on mobility, lack of knowledge about local government functions, male resistance, conservative social values, lack of education and gendered nature of local-level politics all have limited women's effective representation and participation (UNDP, 2003; Nazneen and Tasneem, 2010).

\section{Conclusion}

Participation not only helps local government institutions to reap the benefits of people's feedback on service delivery, but also revitalizes local democratic processes by genuine rather than token empowerment (Carley, 2006). In a decentralized governance system, there are many mechanisms through which people participate in the decision-making process. Popular participation in UP activities is particularly essential to develop the accountability of the local authority, make the program transparent and force the authority to follow the local laws. Moreover, people in the digital era are more involved and well connected with local institutions through electronic means. But all participation does not have equal weight or influence and the public is apathetic about involvement in local governance (Hamilton, 2012). It is indeed evident that successive governments in Bangladesh undertook numerous initiatives with an aim to increase popular participation in the local governing process. Among them, open budget, ward meeting, village court, standing committees and PIC, and right to information are notable features that have been incorporated in the UP. It can be said that the desired objectives of this avenues are yet to attain. It is also argued that participation sometimes may cause delays in the decision making or increases cost or brings conflict. In developing countries like Bangladesh where people are mostly illiterate, not united and not aware about their citizen rights are needed to be more empowered with more participation. Social values, belief systems and norms of rural society do not support the participation of the poor in social and political institutions. Empowerment without capacity building is meaningless as most UP representatives have inadequate knowledge and understanding on their roles and responsibilities and rules of budgeting, planning and managing resources. NGOs and development partners in Bangladesh have been highly regarded as organizers and mobilizers of rural people in terms of empowerment and developing awareness for participation in group activities (Hossain and Matin, 2007). It is expected that they would play a significant role over the period of time to make the UP an effective institution in the governing process. Thus, for making local government bodies effective, accountable, transparent and pro-poor, a strong political vision is necessary that would decentralize more power to local government bodies, would take necessary initiatives to build capacity of local government representatives and would also initiate a program to empower the people by building awareness vis-à-vis their political rights.

\section{References}

Ahmed, T., Rashid, M.H., Ahmmed, K.N. and Razzaque, F. (2016), Social Accountability Mechanisms: A Study on the Union Parishads in Bangladesh, Special Publication Series, No. 2, BRAC Institute of Governance and Development, Dhaka.

Aminuzzaman, S.M. and Sharmin, S. (2006), "Governance mapping: pro-poor governance in rural Bangladesh", in Aminuzzaman, S.M. (Ed.), Governance and Development: Bangladesh and Regional Experiences, Shrabon Prokashani, Dhaka, pp. 165-176. 
PAP

22,1

Barkat, A., Khan, S.H., Majumder, S., Sabina, N., Badiuzzaman, M., Ahmed, K. and Abdullah, M. (2015), Local Governance and Decentralization in Bangladesh: Politics and Economics, Pathak Shamabesh, Dhaka.

Bhatanngar, B. and Williams, A.C. (1992), "Participatory development and the world bank", Discussion Paper No. 183, The World Bank, Washington, DC.

Bird, R.M. (1995), "Financing local services: patterns, problems, and possibilities", Major Report No. 31, Centre for Urban and Community Services, University of Toronto, available at: https://tspace. library.utoronto.ca/handle/1807/91926

Carley, M. (2006), "Partnership and statutory local governance in a devolved Scotland", International Journal of Public Sector Management, Vol. 19 No. 3, pp. 250-260.

Chowdhury, S. (2018), "Decentralized planning and budgeting as social accountability tools: a study of social accountability in local government in Bangladesh", in Ahmed, N. (Ed.), Inclusive Governance in South Asia, Palgrave Macmillan, Cham, pp. 215-234.

CPD (2013), "Finance for local government in Bangladesh: an elusive agenda", CPD-CMI Working Paper No. 6, Centre for Policy Dialogue, Dhaka.

Denhardt, J., Terry, L., Delacruz, E.R. and Andonoska, L. (2009), "Barriers to citizen engagement in developing countries”, International Joumal of Public Administration, Vol. 32 No. 14, pp. 1268-1288.

FEMA (1998), "Union Parishad elections 1997: the report of the fair election monitoring alliance", Fair Election Monitoring Alliance (FEMA), Dhaka.

Government of Bangladesh (2008), Constitution of the People's Republic of Bangladesh, Ministry of Law, Justice and Parliamentary Affairs, The Government of the People's Republic of Bangladesh, Dhaka.

Hamilton, D.K. (1999), Governing Metropolitan Areas: Response to Growth and Change, Garland Publishing, New York, NY.

Hamilton, D.K. (2012), "Does regionalism detract from local democracy? The impact of government scale on participation", Journal of Public Management and Social Policy, Vol. 18 No. 2, pp. 7-23.

Holzer, M. and Kloby, K. (2005), "Public performance measurement an assessment of the state-of-the-art and models for citizen participation", International Journal of Productivity and Performance Management, Vol. 54 No. 7, pp. 517-532.

Hossain, N. and Matin, I. (2007), "Engaging elite support for the poorest? BRAC's targeted ultra poor programme for rural women in Bangladesh", Development in Practice, Vol. 17 No. 3, pp. 380-392.

Isham, J., Narayan, D. and Pritchett, L. (1995), "Does participation improve performance? Establishing causality with subjective data", The World Bank Economic Review, Vol. 9 No. 2, pp. 175-200.

Islam, N. (2016), "Standing committees of Union Parishad: practices and challenges", KILA Journal of Local Governance, Vol. 3 No. 2, pp. 37-46.

Islam, Z. (2015), Strengthening State-led Rural Justice in Bangladesh: Views from the Bottom, 2nd ed., CCB Foundation, Dhaka.

Khan, B.U. and Rahman, M.M. (2009), "Local government level restorative adjudication: an alternative model of justice for children in Bangladesh", Commonwealth Journal of Local Governance, Vol. 4, November, pp. 26-45.

Koenig, H.O. (2005), "Empowerment in local government administration: the case of Elgin, Illinois", The Innovation Journal: The Public Sector Innovation Journal, Vol. 10 No. 1, pp. 1-10.

Litvack, J.I., Ahmad, J. and Bird, R.M. (1998), Rethinking Decentralization in Developing Countries, Sector Studies Series, The World Bank, Washington, DC. 
Local Government Division (2009), Local Government (Union Parishad) Act of 2009, Ministry of Local Government, Rural Development and Cooperatives, The Government of Bangladesh, Dhaka.

Local Government Division (2010), "Baseline survey report on village court in Bangladesh”, Activating Village Courts in Bangladesh Project, Local Government Division (LGD), The Government of Bangladesh, Dhaka.

Local Government Division (2012), Union Parishad Operation Manual, Local Government Division (LGD) and The Government of Bangladesh, Dhaka.

Martinelli, A.S. (2005), "From citizen expression to engagement and empowerment: the case of Olympia, Washington", The Innovation Journal: The Public Sector Innovation Journal, Vol. 10 No. 1, pp. 1-7.

Morshed, M.M.R. (1989), “An approach to Upazila plan in Bangladesh”, The Local Government Quarterly, Vol. 14 No. 1, pp. 3-15.

MRDI and Asia Foundation (2013), Citizens' Access to Information in South Asia: Diagnostic Analysis - Bangladesh Chapter, Management and Resources Development Initiative (MRDI) and The Asia Foundation, Dhaka.

Narayan, D. (2002), "Empowerment and poverty reduction: a sourcebook", The World Bank, available at: http://documents.worldbank.org/curated/en/826661468182372531/Autonomisation-et-reductionde-la-pauvrete (accessed February 1, 2018).

Nazneen, S. and Tasneem, S. (2010), "A silver lining: women in reserved seats in local government in Bangladesh”, IDS Bulletin, Vol. 41 No. 5, pp. 1-7.

Nazneen, S., Ehsan, I. and Hasan, B. (2014), "Exceptional women: reserved councillors in municipal corporation in Bangladesh", in Tadros, M. (Ed.), Women in Politics: Gender, Power and Development, Zed Books, London.

Panday, P.K. (2008), "Representation without participation: quotas for women in Bangladesh", International Political Science Review, Vol. 29 No. 4, pp. 489-512.

Panday, P.K. (2013), Women's Political Participation in Bangladesh, Springer, Dordrecht.

Panday, P.K. and Rabbani, M.H. (2011), "Good governance at the grass-roots: evidence from Union Parishads in Bangladesh", South Asian Survey, Vol. 18 No. 2, pp. 293-315.

Parsons, R.J. (1988), "Empowerment for role alternatives for low income minority girls: a group work approach", Social Work with Groups, Vol. 11 No. 4, pp. 27-43.

Rahman, A., Kabir, M. and Razzaque, A. (2004), Civic Participation in Sub-national Budgeting in Bangladesh, The World Bank Institute, Washington, DC.

Roberts, N. (2004), "Public deliberation in an age of direct citizen participation", American Review of Public Administration, Vol. 34 No. 4, pp. 315-353.

Roche, B. (2010), New Directions in Community-based Research, Wellesley Institute, Toronto.

Sarker, A.E. (2003), "The illusion of decentralization: evidence from Bangladesh", The International Journal of Public Sector Management, Vol. 16 No. 7, pp. 523-548.

Sarker, A.E. (2006), "The political economy of decentralized governance: an assessment of rural local government reforms in Bangladesh", International Journal of Public Administration, Vol. 29 No. 13, pp. 1285-1309.

Sarker, N.I. (2013), "An evaluation of village court: a study on selected village courts", unpublished Master thesis, Institute of Governance Studies, BRAC University, available at: http://hdl.handle. net/10361/3506

Siddiqui, K. (2005), Local Government in Bangladesh, The University Press, Dhaka.

Sultan, M. (2018), "Women's representation and participation in local government in Bangladesh: new openings and remaining barriers", in Ahmed, N. (Ed.), Women in Governing Institutions in South Asia, Palgrave Macmillan, Cham, pp. 245-265.

The World Bank (1994), The World Bank and Participation, Operations Policy Department, Washington, DC. 
PAP

22,1

Uddin, N. (2016), "Recent trends of local government elections in Bangladesh: an analysis on profile and politics", Public Affairs and Governance, Vol. 4 No. 1, pp. 166-184.

Uddin, N. (2017), "Empowerment through decentralization: conceptions, contrivances and connections", Dynamics of Public Administration, Vol. 34 No. 1, pp. 86-101.

UNDP (2003), "Sirajganj Local Governance Development Fund Project: mid-term evaluation (draft report)", Sirajganj Local Governance Development Fund Project, Dhaka.

Vergara, V.M. (2002), Participatory Municipal Budgeting as a Tool to Establish Accountable Governance, The World Bank Institute, Washington, DC.

Vigoda, E. and Golembiewski, R.T. (2001), "Citizenship behavior and the spirit of new managerialism: a theoretical framework and challenge for governance", The American Review of Public Administration, Vol. 31 No. 3, pp. 273-295.

Waheduzzaman (2010), "People's participation for good governance: a study of rural development programs in Bangladesh", unpublished doctoral thesis, School of Management and Information Systems, Faculty of Business and Law, Victoria University.

Wallerstein, N. (1992), "Powerlessness, empowerment, and health: implications for health promotion programs", American Journal of Health Promotion, Vol. 6 No. 3, pp. 197-205.

Wilson, P. (1996), "Empowerment: community economic development from the inside out", Urban Studies, Vol. 33 Nos 4-5, pp. 617-630.

Zeemering, E.S. (2008), "Governing interlocal cooperation: city council interests and the implications for public management”, Public Administration Review, Vol. 68 No. 4, pp. 731-742.

Zimmerman, M.A. and Rappaport, J. (1988), "Citizen participation, perceived control and psychological empowerment”, American Journal of Community Psychology, Vol. 16 No. 5, pp. 725-750.

\section{About the author}

Nasir Uddin, obtained his BSS and MSS degrees from the University of Dhaka, is serving as Assistant Professor of Public Administration at the University of Chittagong (CU) in Bangladesh. He has written about ten peer-reviewed publications, including a book and more than 20 newspaper articles. He has initiated and conducted many research projects regarding social protection programs, access to local justice and e-governance that were submitted to the CU research and publication office, CU research cell and social science research council under planning division of the Bangladeshi Government. He also served at Social Impact as National Team Member for the final performance evaluation of USAID-funded "Democratic Participation and Reform (DPR)" project in 2017 and the mid-term evaluation of "Strengthening Political Landscape (SPL)" activity in 2019. Before joining CU, he worked as Research Associate at Human Development Research Centre for which he worked at Swiss Agency for Development and Cooperation, United Nations Development Programme and United Nations Population Fund, Bangladesh. Nasir Uddin can be contacted at: nasir095@yahoo.com

For instructions on how to order reprints of this article, please visit our website:

www.emeraldgrouppublishing.com/licensing/reprints.htm

Or contact us for further details: permissions@emeraldinsight.com 